\author{
Patrycja Krawczyk \\ Politechnika Częstochowska \\ e-mail: patrycja.krawczyk@wz.pcz.pl
}

\title{
KONWERGENCJA STANDARDÓW SPRAWOZDAWCZOŚCI FINANSOWEJ DO NORM MIĘDZYNARODOWYCH
}

\section{CONVERGENCE OF FINANCIAL REPORTING STANDARDS FOR INTERNATIONAL NORMS}

DOI: $10.15611 / \mathrm{pn} .2018 .523 .17$

JEL Classification: M4, F15

Streszczenie: Rachunkowość jako uniwersalny język biznesu powinna być zrozumiała bez względu na szerokość geograficzną. Koniec XX i początek XXI wieku to okres globalizacji wielu obszarów życia społecznego i gospodarczego, w tym także rachunkowości. Następuje wiele procesów standaryzacji i harmonizacji w skali globalnej. Oba te terminy są stosowane zamiennie, choć trzeba zauważyć, że standaryzacja oznacza wprowadzenie jednolitych norm. Celem opracowania jest podkreślenie roli standaryzacji sprawozdawczości finansowej w rozwoju globalnej gospodarki. Zaprezentowany zostanie proces, jaki po 1989 roku przeszła Polska, dostosowując prawo bilansowe do norm międzynarodowych. W przygotowaniu opracowania wykorzystana została metoda krytycznej analizy literatury, raportów branżowych, a także znajdą się tu odwołania do obserwacji praktyki gospodarczej, własnych doświadczeń i przemyśleń.

Słowa kluczowe: harmonizacja, globalizacja, konwergencja, rachunkowość, standaryzacja.

Summary: Accounting as a universal business language should be understood all over the world. The end of the 20th and the beginning of the 21st century is the period of globalization of many areas of social and economic life, including accounting. There are a number of processes for standardization and harmonization on a global scale. These two terms are used interchangeably, although it should be noted that standardization means the introduction of uniform standards. Harmonization is the process of adapting the legal system in two or more states. In a financial reporting context, convergence is the process of harmonising accounting standards issued by different regulatory bodies. One example might be the convergence of International Accounting Standards (IAS) and US Standards. The purpose of the study is to underline the role of standardization of financial reporting in the development of the global economy. An example of Poland will be explored. The preparation of the paper will utilize the method of critical literary analysis, industry reports, as well as references to the observance of business practice, author own experience and reflection.

Keywords: harmonization, globalization, convergence, accounting, standardization. 


\section{Wstęp}

Zasadniczym celem rachunkowości jest tworzenie rzetelnego obrazu działalności podmiotów gospodarczych, głównie w postaci sprawozdawczości. Sprawozdanie finansowe prezentuje efekty zarządzania przez kierownictwo powierzonymi mu zasobami. Zaprezentowany obraz powinien charakteryzować się takimi fundamentalnymi cechami, jak użyteczność informacji finansowych i wierne przedstawienie. Użyteczność sprawozdania zwiększa się, jeżeli informacja jest dodatkowo porównywalna, weryfikowalna, podana w odpowiednim czasie i zrozumiała. Porównywalność jest słowem kluczowym z punktu widzenia niniejszego opracowania. Porównywać można bowiem wyniki finansowe w poszczególnych okresach sprawozdawczych, często jednak zachodzi potrzeba odniesienia danych do innych podmiotów.

Rozumienie globalizacji dalekie jest od jednoznaczności, istnieje wiele definicji, a sama ocena tego zjawiska jest zależna od tego, czy akceptuje się bieżące trendy światowej gospodarki i kultury, czy też brakuje akceptacji zmienności świata. Pewne jest, że zjawiska tego nie można powstrzymać, gdyż obejmuje praktycznie każdy wymiar aktywności. Globalizacja gospodarki wymusiła także zmiany w rachunkowości, która pretenduje do miana międzynarodowego języka biznesu. Nasuwa się jednak pytanie: „czy wszyscy księgowi na świecie mówią tym samym językiem” [Smith 2010].

Odmienność systemów rachunkowości poszczególnych krajów ukształtowana została wieloma czynnikami, w tym ekonomicznymi, prawnymi czy kulturowymi. Skutkiem tego jest, że sprawozdania finansowe, sporządzane na podstawie obowiązujących w danym kraju regulacji prawnych, są nieporównywalne. Taki stan rzeczy może powodować błędne decyzje gospodarcze. Dynamiczny rozwój międzynarodowych rynków kapitałowych i rosnąca liczba ponadnarodowych korporacji, polityczna i gospodarcza integracja oraz internacjonalizacja działalności przedsiębiorstw wymagają ujednolicenia zasad rachunkowości na poziomie międzynarodowym oraz implementowania tych zasad do krajowych modeli rachunkowości. Celem opracowania jest prezentacja znaczenia standaryzacji uregulowań prawa bilansowego w skali międzynarodowej. Ujednolicenie rachunkowości postępuje od wielu lat, nie jest to jednak proces zakończony, gdyż uregulowania rachunkowości muszą odpowiadać na zmiany zachodzące $\mathrm{w}$ turbulentnym otoczeniu gospodarczym. Wśród wyzwań współczesnej rachunkowości należy wymienić: kulturowe uwarunkowania, wpływ nowoczesnych technologii, zrównoważony rozwój, finansyzację [Biadacz 2016]. W proces ten aktywnie zostały włączone polskie uregulowania prawa bilansowego. 


\section{Konwergencja, standaryzacja, harmonizacja}

Konwergencja jest pojęciem multidyscyplinarnym, które może charakteryzować wiele obszarów życia. Słownikowo pojęcie to definiowane jest jako proces, w którym różne zjawiska, początkowo niepodobne i niespokrewnione, zbliżają się i upodabniają do siebie (w przeciwieństwie do dywergencji). W taki sposób określa się też wynik tego procesu, tzn. występowanie podobnych cech w zjawiskach, które takiemu procesowi podlegały [http://www.sjp.pwn.pl]. Konwergencja obejmuje wiele obszarów aktywności gospodarczej. Najbardziej rozpowszechniona wydaje się teoria konwergencji mówiąca o wyrównywaniu poziomów rozwoju gospodarczego państw (zob. tab. 1). Na gruncie tych założeń powstały kryteria konwergencji, czyli wprowadzone przez Traktat o funkcjonowaniu Unii Europejskiej wskaźniki ekonomiczne i zasady, jakie powinno spełniać państwo aspirujące do pełnego uczestnictwa w Unii Gospodarczej i Walutowej [Traktat o funkcjonowaniu UE 2004].

Tabela 1. Multidyscyplinarne odniesienia pojęcia konwergencji

\begin{tabular}{|l|l|}
\hline \multicolumn{1}{|c|}{ Dyscyplina } & \multicolumn{1}{c|}{ Definicja } \\
\hline Biologia & $\begin{array}{l}\text { Proces powstawania morfologicznie i funkcjonalnie podobnych cech w grupach } \\
\text { organizmów odlegle spokrewnionych w odpowiedzi na podobne lub takie same } \\
\text { wymagania środowiskowe. }\end{array}$ \\
\hline Medycyna & Jednoczesny ruch gałek ocznych. \\
\hline Multimedia & $\begin{array}{l}\text { W tym obszarze wyróżnia się konwergencję mimetyczną i mimikryczną. Mi- } \\
\text { metyczna to upodabnianie się form przekazu w mediach tradycyjnych do form } \\
\text { przekazu w mediach nowoczesnych (Internet, TV), a mimikryczna to proces od- } \\
\text { wrotny. }\end{array}$ \\
\hline Telekomunikacja & $\begin{array}{l}\text { Eączenie ofert internetowych, telefonicznych i telewizyjnych na bazie technolo- } \\
\text { gii mobilnych i stacjonarnych, z których można korzystać wszędzie i na różnych } \\
\text { urządzeniach. }\end{array}$ \\
\hline Meteorologia & $\begin{array}{l}\text { Zbliżanie się ku sobie linii prądu powietrza na określonym obszarze lub wzdłuż } \\
\text { pewnej linii. Najważniejszym rezultatem konwergencji jest unoszenie powietrza } \\
\text { ku górze, co łączy się z ochładzaniem, wzrostem wilgotności, rozwojem zach- } \\
\text { murzenia i występowaniem opadów atmosferycznych. }\end{array}$ \\
\hline Ekonomia & $\begin{array}{l}\text { W ekonomii powstała teoria konwergencji mówiąca, że w krajach biedniejszych } \\
\text { dochody na mieszkańca rosną szybciej niż w krajach bogatych. W rezultacie w } \\
\text { długiej perspektywie wszystkie społeczeństwa powinny żyć na podobnym, wy- } \\
\text { sokim poziomie. Zaprzeczeniem tej teorii jest istnienie krajów biednych. }\end{array}$ \\
\hline
\end{tabular}

Źródło: opracowanie własne na podstawie [www.sjp.pwn.pl].

Jak już wspomniano we wstępie, rachunkowość, która za pomocą wartości liczbowych opisuje efekty aktywności gospodarczej, ewoluuje, by sprostać wyzwaniom globalnego rynku. Konwergencji ulegają kolejne obszary życia, a co za tym idzie, zaistniała potrzeba, by w proces ten włączona została rachunkowość. Potrzeba jednolitej informacji generowanej w procesie rachunkowości została zauważona już 
w latach pięćdziesiątych XX wieku ze względu na wzrost na dużą skalę przepływów kapitałowych i towarowych [Rymarczyk 2004]. Zaobserwowano, że regulacje prawne rachunkowości z różnych krajów powinny zostać znormalizowane, warunek jednolitości powinien spowodować, że te same regulacje prawne nie są różnie interpretowane i stosowane, ta sama zaś sytuacja ekonomiczno-prawna przedsiębiorstwa nie jest różnie regulowana i różnie traktowana przez odbiorców informacji. W efekcie ujednolicanie regulacji prawnych rachunkowości przybrało formę:

- harmonizacji regulacji rachunkowości,

- standaryzacji regulacji rachunkowości.

Oba te terminy używane są w odniesieniu do rachunkowości często zamiennie. Jednak harmonizacja to proces polegający na dostosowywaniu odmiennych regulacji prawnych, natomiast standaryzacja oznacza wprowadzenie jednolitych norm. Rozróżnienie tych dwóch pojęć najlepiej opisuje stwierdzenie: harmonizacja oznacza współistnienie różnorodności, standaryzacja zaś oznacza monopol [Dobija 2009]. Najbardziej pojemne i ogólne wydawać by mogło się używanie słowa „konwergencja" celem opisania procesów globalizacji norm prawnych rachunkowości.

Sama konwergencja w rachunkowości może być rozumiana w różny sposób. W odniesieniu do rachunkowości finansowej i zarządczej konwergencja oznacza zbieżność między tymi obszarami (stan) lub tworzenie się tej zbieżności (proces). Problem ten rozważa P. Kabalski [2012], odnosząc go do praktyki przedsiębiorstw z różnych państw. Jednak częściej mianem konwergencji określana jest także próba wypracowania jednego ogólnoświatowego zestawu standardów przez dwa oddzielne podmioty: Radę Standardów Rachunkowości Finansowej (Financial Accounting Standards Board - FASB) i Radę Międzynarodowych Standardów Rachunkowości (International Accounting Standards Board - IASB).

\section{Geopolityka rachunkowości}

Współczesny kształt zasad rachunkowości opiera się na różnych tradycjach. Dwa nurty wysuwają się na pierwszy plan. Pierwszy z nich to nurt anglosaski, charakterystyczny dla: Wielkiej Brytanii, Stanów Zjednoczonych, Kanady, Australii, państw skandynawskich, Holandii. Rachunkowość jest tu podporządkowana potrzebom rynku kapitałowego (jest nim głównie giełda) i jego uczestników (informacje dla inwestorów). Sprawozdania finansowe mają wiernie prezentować sytuację finansową i dokonania przedsiębiorstw. W modelu tym mamy do czynienia $\mathrm{z}$ wyższością treści ekonomicznych nad formą prawną. Ze względu na tak określony cel transakcje i zdarzenia gospodarcze ujmuje się zgodnie z ich treścią ekonomiczną (a nie wyłącznie zgodnie z formą prawną), a zasada współmierności ma przewagę nad zasadą ostrożności.

Drugi znaczący nurt, zwany kontynentalnym, wywodzi się z niemieckiej kultury ekonomicznej. Ma na celu ochronę interesów wierzycieli, z silnym akcentem na zasadę ostrożności. Jest on silnie regulowany przez prawo. Rozwiązania stosowane 
w rachunkowości są bardzo konserwatywne, a informacje tworzone przez rachunkowość są podporządkowane głównie wymogom stawianym przez rząd (np. dla celów ustalania zobowiązań podatkowych).

Wyrazem harmonizacji rachunkowości była IV dyrektywa unijna z 1978 roku, ale także powstanie w 1973 roku Komitetu Międzynarodowych Standardów Rachunkowości - KMSR (IASC - International Accounting Standards Commitee) oraz Rady Standardów Rachunkowości Finansowej (FASB - Financial Accounting Standards Bard).

Komitet Międzynarodowych Standardów Rachunkowości został założony przez 16 organizacji zawodowych z dziedziny rachunkowości z 10 krajów (Australia, Kanada, Francja, Niemcy, Japonia, Meksyk, Holandia, Wielka Brytania, Stany Zjednoczone). 1 kwietnia 2001 roku KMSR został zastąpiony przez Radę Międzynarodowych Standardów Rachunkowości - RMSR (IASB - International Accounting Standards Board), która skupia obecnie 122 organizacje zawodowe z 91 państw, w tym także z Polski (Stowarzyszenie Księgowych w Polsce). Siedziba IASB znajduje się w Londynie. Reguły wypracowywane są w kontynentalnym nurcie rachunkowości. Głównym celem organizacji jest ujednolicenie zasad rachunkowości stosowanych przez przedsiębiorstwa i inne organizacje. Jest on realizowany przez:

- formułowanie i publikowanie, zgodnie z interesem publicznym, standardów rachunkowości, które powinny być przestrzegane podczas prezentacji sprawozdań finansowych,

- promowanie standardów w celu ich akceptacji i przestrzegania na całym świecie,

- działalność zmierzającą do poprawy i harmonizacji regulacji (standardów) rachunkowości oraz procedur związanych z przygotowaniem i prezentacją sprawozdań finansowych.

Rada Standardów Rachunkowości Finansowej funkcjonująca na terenie Stanów Zjednoczonych jest instytucją niepubliczną, tworzącą standardy rachunkowości zwane Ogólnie Akceptowanymi Zasadami Rachunkowości (Generally Accepted Accounting Principles - US GAAP). Standardy stosowane są przez spółki notowane na nowojorskiej giełdzie i wiele prywatnych przedsiębiorstw w Stanach Zjednoczonych. Wynikające z rachunkowości typu anglosaskiego US GAAP przyjmują prawdziwy i wierny wizerunek finansowy firmy jako nadrzędny cel rachunkowości, są zorientowane na rynek kapitałowy i inwestorów, zakładają dominację treści nad formą i regulacjami prawa bilansowego, preferują ryzyko w działalności gospodarczej.

Również niektóre z krajów europejskich dopuszczają możliwość sporządzania skonsolidowanych sprawozdań jednostek dopuszczonych do publicznego obrotu według zasad określonych przez US GAAP. W odróżnieniu od MSSF US GAAP odnoszą się do anglosaskiego typu rachunkowości. Oznacza to orientację na podejście ekonomiczne i ryzyko. Z kolei koncepcje rachunkowości zgodne z Międzynarodowymi Standardami Sprawozdawczości Finansowej wspierają bezpieczeństwo i stabilność obrotu gospodarczego. 
Obecnie obserwujemy współpracę między IASB a FASB. Ma ona na celu wypracowanie jednego ogólnoświatowego zestawu standardów [Topazio 2008]. W 2002 roku organizacje te podpisały tzw. umowę z Norwalk, której celem jest współpraca i redukcja różnic między MSR i US GAAP. Porozumienie między IASB a FASB nazywane jest konwergencją. Podstawowym celem współpracy jest opracowanie Ram Konceptualnych sprawozdawczości finansowej, które mają być podstawą globalnych standardów rachunkowości.

\section{Dostosowanie uregulowań do wymogów międzynarodowych - przykład Polski}

Transformacja gospodarki polskiej po 1989 roku, z centralnie sterowanej do wolnorynkowej, stawiana jest za wzór. Przekształceń i dostosowań wymagało wiele obszarów, jednym z nich były uregulowania prawne rachunkowości. Polska stopniowo włączała się w proces harmonizacji i standaryzacji, miała ona jednak sytuację trudniejszą niż państwa, w których gospodarka rynkowa miała długoletnie tradycje. Droga do standaryzacji musiała się rozpocząć od przekształcenia rachunkowości uwarunkowanej przez system socjalistyczny do rachunkowości postrzeganej przez pryzmat wolnego rynku (gospodarki kapitalistycznej).

Choć pewne zasady rachunkowości w okresie socjalizmu były takie same jak w innych krajach (np. zasada podwójnego zapisu, inwentaryzacja), zmianie musiały ulec cele i zadania rachunkowości. W okresie od 1945 roku do przełomu w 1989 roku rachunkowość w Polsce obejmowała: ewidencję księgową, tj. rejestrację zdarzeń, rachunek kosztów (celem opisu, a nie kontroli zarządczej) oraz sprawozdawczość finansową jako połączenie rachunkowości ze statystyką państwową na poziomie makroekonomicznym [Jurewicz 2013]. Pojawienie się wolnego kapitału, a tym samym inwestorów, zmuszało do przekształceń sprawozdań finansowych, by dostosować do potrzeb nowych użytkowników.

W okresie ewolucji polskiego prawa bilansowego po roku 1989 należy wyodrębnić kilka przełomowych momentów:

- 1991 rok - wprowadzono Rozporządzenie Ministra Finansów w sprawie zasad prowadzenia rachunkowości [Rozporządzenie 1991], które już było wzorowane na dyrektywach Unii Europejskiej. Wśród wielu uregulowań wprowadzony został wzór bilansu i rachunku wyników w dwóch wersjach: porównawczej i kalkulacyjnej, dodatkowo ujęto minimum informacji uzupełniających. Rozporządzenie było rozwiązaniem przejściowym;

- 1994 rok - wprowadzono ustawę [Ustawa 1994], która została oparta na IV, VII i VIII dyrektywie UE, wprowadzając także wiele rozwiązań zaczerpniętych z międzynarodowych standardów rachunkowości, m.in. rachunek przepływów pieniężnych. Ordynacja ta stworzyła solidne podwaliny konstrukcyjne nowoczesnych rozwiązań rachunkowości, była wielokrotnie nowelizowana, by dopaso- 
wać się do wymagań i warunków rozwijającej się gospodarki rynkowej. Zmiany mają wieloraki charakter, w tym rozwinięto i doprecyzowano definicje, uproszczono zasady dotyczące inwentaryzacji, zmieniono wzory sprawozdań, dostosowano zasady rachunkowości do wymogów ery komputerowej;

- 2004 rok i przystąpienie do Unii Europejskiej spowodowało konieczność zmiany polskiego prawa bilansowego - nowelizacje z kwietnia (Dz.U. 2004, nr 145, poz. 1535) i sierpnia 2004 roku (Dz.U. 2004, nr 214, poz. 2153 z późn. zm.) wprowadziły szereg nowoczesnych rozwiązań wzorowanych na międzynarodowych standardach sprawozdawczości finansowej oraz na zmodernizowanych dyrektywach rachunkowości UE.

Dyrektywy unijne są bardziej ogólne niż MSR i zasadniczo nie wchodzą w kolizję z nimi. Jednak w niektórych obszarach uregulowań istnieją sprzeczności między postanowieniami MSR, dyrektywami UE czy rozwiązaniami ustawy o rachunkowości. MSR (wynikające z rachunkowości kontynentalnej) są zorientowane na rynek i instytucje kredytowe, preferują stabilność działalności gospodarczej, bazują na szczegółowej kodyfikacji prawa bilansowego odnośnie do zasad, metod i technik rachunkowości, struktur informacyjnych sprawozdań finansowych, zasadzie nadrzędności prawa nad faktami, konserwatyzmie i ostrożności, ścisłym powiązaniu prawa bilansowego z prawem podatkowym itd.

\section{Podsumowanie}

Efektywność globalnych rynków kapitałowych zależy od zdolności podmiotów sporządzających sprawozdania finansowe do komunikowania się z inwestorami poprzez sprawozdania finansowe. Konwergencja standardów rachunkowości wymaga rozległych i kosztownych zmian w infrastrukturze ustalania standardów i egzekwowania prawa w poszczególnych krajach, a także odpowiednich szkoleń dla kierownictwa, biegłych rewidentów i inwestorów. Proces ten, choć trudny, musi następować tak, jak następuje globalizacja procesów gospodarczych.

Każda jednostka gospodarcza powinna przyjąć właściwe dla niej zasady wewnętrzne będące jej polityką rachunkowości. Podstawowym aktem prawnym, który reguluje obszar rachunkowości w Polsce, jest Ustawa o rachunkowości z dnia 29 września 1994 roku (wielokrotnie nowelizowana). W sprawach nieuregulowanych przepisami ustawy, przyjmując zasady (politykę) rachunkowości, jednostki mogą stosować krajowe standardy rachunkowości wydane przez Komitet Standardów Rachunkowości. W przypadku braku odpowiedniego standardu krajowego podmioty mogą stosować Międzynarodowe Standardy Rachunkowości. 


\section{Literatura}

Biadacz R., 2016, Czynniki warunkujące rozwój rachunkowości w XXI wieku - wybrane problemy, Finanse, Rynki Finansowe, Ubezpieczenia, nr 2(80), cz. 2, s. 21-29.

Dobija D., 2009, O procesach standaryzacyjnych w rachunkowości, Master of Business Administration, vol. 17 , nr 3, s. 42-49.

Jurewicz A., 2013, Ewolucja przepisów rachunkowości w Polsce na tle harmonizacji i standaryzacji rachunkowości w skali międzynarodowej, Studia Ekonomiczne Regionu Łódzkiego, nr 11, PTE, Łódź, s. 83-102.

Kabalski P., 2012, Konwergencja rachunkowości finansowej i zarządczej pod wpływem Międzynarodowych Standardów Sprawozdawczości Finansowej, Zeszyty Teoretyczne Rachunkowości, tom 66 (122), SKwP, Warszawa, s. 57-73.

Rymarczyk J., 2004, Internacjonalizacja i globalizacja przedsiębiorstwa, PWE, Warszawa.

Smith M., 2010, Convergence in Accounting Standards: Insights from Academicians and Practitioners, Advances in Accounting, https://www.researchgate.net/publication.

Topazio N., 2008, Convergence of Accounting Standards, The Chartered Institute of Management Accountants CIMA, Londyn.

Traktat o funkcjonowaniu Unii Europejskiej, Dz. U. 2004.90.864/2, art. 140.

http://www.sjp.pwn.pl (06.09.17).

Rozporządzenie Ministra Finansów w sprawie prowadzenia rachunkowości z 1991 roku, Dz. U. nr 10, poz. 35 .

Ustawa o rachunkowości z dnia 29 września 1994 roku, Dz.U. nr 121, poz. 591. 